\title{
To Be (a State) or Not to Be?
}

\author{
The Relevance of the Law of Belligerent \\ Occupation with regard to Palestine's Statehood \\ before the ICC
}

\author{
Robert Heinsch* and Giulia Pinzauti**
}

\begin{abstract}
One of the traditional criteria for statehood under the Montevideo Convention is that an entity possesses an 'effective government'. Against this backdrop, this article discusses the impact of belligerent occupation on Palestine's ability to possess an effective government, and thus fulfil the criteria for statehood. It argues that, as a matter of law, the requirement of effective government should not be interpreted strictly. Statehood does not require an immutable threshold of effectiveness; rather, the criterion has been flexibly interpreted and applied in practice. Belligerent occupation is a factual circumstance calling for such a flexible interpretation. While occupation impairs an occupied entity's ability to exercise the functions of government, it does not affect statehood. Within the framework of the Rome Statute, the fact that the Court has jurisdiction over situations of belligerent occupation confirms this interpretation. Moreover, when assessing whether an occupied entity meets the criteria for statehood, deficiencies in effectiveness should be weighed against the principle of self-determination and international recognition. Applying those considerations to Palestine's situation, the conclusion seems warranted that it meets
\end{abstract}

* Associate Professor of Public International Law, Grotius Centre for International Legal Studies, Leiden Law School and Director of the Kalshoven-Gieskes Forum on International Humanitarian Law and its IHL Clinic [r.w.heinsch@law.leidenuniv.nl]

** Assistant Professor of Public International Law, Grotius Centre for International Legal Studies, Leiden Law School and Deputy Director of the IHL Clinic of the Kalshoven-Gieskes Forum [g. pinzauti@law.leidenuniv.nl].

This article is based on the authors' amicus curiae submission on the scope of the ICC's territorial jurisdiction before Pre-Trial Chamber I: Submission pursuant to Rule 103 (Robert Heinsch \& Giulia Pinzauti), Situation in the State of Palestine (ICC-01/18), Pre-Trial Chamber I, 16 March 2020. The authors wish to thank their IHL Clinic students Ahmed Abofoul, Icarus Chan, Alessandra da Costa e Silva, Dorine Nauleau and Juliette Wangen for their invaluable research assistance. All errors are the authors' responsibility only. Both authors have previously cooperated with a Palestinian Human Rights NGO and have visited Israel as well as the Occupied Palestinian Territories on several occasions. All websites were last visited on 1 June 2020. 
the criteria for statehood under general international law and can thus validly trigger the Court's jurisdiction to investigate and prosecute alleged crimes committed on its territory.

\section{Introduction}

One of the most prominent questions raised by the Situation in Palestine before the International Criminal Court (ICC) is whether Palestine is not only a state party to the Rome Statute but also if it is capable of triggering the Court's jurisdiction to investigate and prosecute alleged crimes committed on its territory. This question can be answered at two different levels. First, by reference to the legal framework of the Rome Statute, applying a functional notion of statehood, and second, by using the relevant rules of public international law. In our view, as we have argued elsewhere, ${ }^{1}$ there are compelling reasons to conclude that Palestine should be regarded as a state within the framework of the Rome Statute, and that it validly triggered the Court's jurisdiction pursuant to Articles 12(2)(a) and 14 of the Statute. Accordingly, there is no need to ascertain whether Palestine fulfils the commonly accepted criteria for statehood under general international law, as codified in the 1933 Montevideo Convention on the Rights and Duties of States. ${ }^{2}$ Nevertheless, if the Court decides to analyse Palestine's statehood under general international law, the Court should take into account the impact of belligerent occupation as governed by international humanitarian law (IHL) on Palestine's ability to fulfil the criteria for statehood. Notably, the impact of occupation on statehood is key for the assessment of Palestine's statehood beyond the current proceedings before the ICC.

While the question of Palestine's statehood is still hotly contested and widely debated, ${ }^{3}$ the impact of occupation on statehood has not received adequate attention either in the Prosecutor's request for a ruling on the Court's territorial jurisdiction, ${ }^{4}$ or in scholarly discussions. ${ }^{5}$ Many deny Palestine's

1 R. Heinsch and G. Pinzauti, Submission pursuant to Rule 103 (Robert Heinsch \& Giulia Pinzauti), Situation in the State of Palestine (ICC-01/18), Pre-Trial Chamber I, 16 March 2020 (hereafter Heinsch and Pinzauti Amicus Brief).

2 Montevideo Convention on the Rights and Duties of States, opened for signature 26 December 1933 (entered into force 26 December 1934) (hereafter Montevideo Convention). It is the authors' view that the Montevideo criteria are not the final litmus test of statehood, and should be applied together with other factors. See infra, Section 4.

3 See e.g. S. Kay and J. Kern, 'The Statehood of Palestine and Its Effect on the Exercise of ICC Jurisdiction', Opinio Juris, 5 July 2019, available online at http://opiniojuris.org/2019/ 07/05/the-statehood-of-palestine-and-its-effect-on-the-exercise-of-icc-jurisdiction $\% \mathrm{EF} \% \mathrm{BB} \% \mathrm{BF} /$; J. Vidmar, 'Palestine and the Conceptual Problem of Implicit Statehood', 12 Chinese Journal of International Law (2013) 19-41; J.V. Whitback, 'The State of Palestine Exists', XVIII Middle East Policy (2011) 62-66; J. Crawford, The Creation of States in International Law (2nd edn., OUP, 2007), at 434-448.

4 Prosecution request pursuant to art. 19(3) for a ruling on the Court's territorial jurisdiction in Palestine, Situation in the State of Palestine (ICC-01/18-12), Pre-Trial Chamber I, 22 January 2020, § 220 (hereafter Prosecution Request).

5 For a brief discussion of the effects of occupation on statehood see J. Quigley, The Statehood of Palestine (CUP, 2012), at 219-225. 
statehood on the basis that it fails to satisfy the Montevideo criterion of "effective government'. Those who adopt this view argue that the issues that were reserved for permanent status negotiations in the Oslo Accords - namely Jerusalem, settlements, specified military locations, borders, foreign relations, Israelis, and refugees ${ }^{6}$ - fall outside Palestine's governmental powers, and therefore diminish the criterion of effective government. ${ }^{7}$ Moreover, they claim that Palestine does not exercise governmental authority over the Gaza Strip, which is administered by Hamas, and only has limited authority over Area $\mathrm{C}$ in the West Bank. ${ }^{8}$ Thus - the argument goes — Palestine lacks the necessary effectiveness to be considered a state under international law. Yet, Israel's occupation raises key questions about Palestine's ability to have an effective government and has a bearing on the proper interpretation and application of the criteria for statehood to the case of Palestine. Similar considerations apply to other entities that may claim statehood while under a regime of belligerent occupation. This article purports to address this gap.

This contribution argues that, in deciding the question of Palestine's statehood under general international law, one should take into account the effects of Israel's protracted occupation on Palestine's full exercise of sovereignty over the Occupied Palestinian Territory (OPT). Moreover, the occupation should be weighed against other factors that mitigate the deficiencies in Palestine's effectiveness. Such a flexible application of the criteria for statehood is also in accordance with international precedent in this context, as shown below.

In Section 2, this article discusses the criteria for statehood under general international law, focusing on the requirement of effective government, and arguing that it is a relative condition. Section 3 addresses the effects of belligerent occupation on the occupied entity's ability to exercise the functions of government. It also discusses the effects of breaches of IHL by the occupant. Section 4 argues that deficiencies in the effectiveness of occupied territories should be weighed against other factors, such as the principle of selfdetermination and international recognition. Section 5 further shows that the Rome Statute intrinsically assumes that the ICC can have jurisdiction over territories under occupation. Finally, Section 6 draws some overall conclusions.

6 Israeli-Palestinian Interim Agreement on the West Bank and the Gaza Strip, 28 September 1995, 37 ILM (1997) 551 ('Oslo II'), Art. XVII(1)(a).

7 Kay and Kern, supra note 3; M.N Shaw, Submission of Observations to the Pre-Trial Chamber pursuant to Rule 103, Situation in the State of Palestine (ICC-01/18), Pre-Trial Chamber I, 16 March 2020 (hereafter Shaw Amicus Brief), \$§ 30-31.

8 State of Israel Office of the Attorney General, The International Criminal Court's Lack of Jurisdiction over The So-Called 'Situation in Palestine', 20 December 2019, § 37. 


\section{The Criterion of Government under the Montevideo Convention is Relative}

There is no 'generally accepted and satisfactory legal definition of statehood' in international law. ${ }^{9}$ Different scholars have proposed different conceptions, depending on the importance attached to criteria such as effectiveness, recognition and legitimacy. The classic test for statehood is based on effectiveness and requires the fulfilment of four objective criteria, as laid down in Article 1 of the 1933 Montevideo Convention on the Rights and Duties of States: '(a) a permanent population; (b) a defined territory; (c) a government; and (d) capacity to enter into relations with other States. ${ }^{10}$ Under this conception of statehood, recognition is declaratory and not constitutive. ${ }^{11}$ In other words, recognition by other states or group of states is only evidence that an entity meets the criteria for statehood, but it is not a pre-requisite. This conception of recognition also operates as a safeguard against situations where an entity is not accepted as a new state because of political reasons despite the fact that it fulfils all necessary criteria.

There is growing consensus amongst scholars that the Montevideo criteria do not represent 'the exclusive and determinative hallmarks of statehood'12 although, as mentioned earlier, there is still a considerable level of disagreement on what the proper legal test for statehood is. ${ }^{13}$ The Montevideo criteria reflect the dominant notion of statehood at the time when they were drafted in 1933. Since then, the emergence of other principles of international law such as the prohibition of the threat or use of force, and the principle of selfdetermination of peoples — has to some extent affected the way in which statehood is conceptualized and assessed. ${ }^{14}$ As a consequence, the Montevideo criteria cannot be seen as fully embodying the conditions for statehood. For instance, there are examples of entities that have been recognized as states despite the fact that they lacked the effectiveness required under the Montevideo criteria, particularly in the context of the decolonization process. ${ }^{15}$ Contrarily, we find examples of effective entities that have not been recognized as states because their creation resulted from acts in violation of international law, for instance from territorial acquisition by force or in violation of the right to self-determination. ${ }^{16}$ In other words, although the Montevideo criteria have not been completely superseded by the emergence of new rules on statehood,

9 Crawford, supra note 3 , at 37.

10 Art. 1 Montevideo Convention.

11 M. Craven and R. Parfitt, 'Statehood, Self-determination and Recognition', in M.D. Evans (ed.), International Law (5th edn., OUP, 2018), at 192.

12 Z. Saltzman, 'Much Ado About Nothing: Non-Member State Status, Palestine and the International Criminal Court', 3 Journal of International and Comparative Law (2013) 163209, at 173. See also M.N. Shaw, International Law (8th edn., CUP, 2017), at 158; J. Crawford, Brownlie's Principles of Public International Law (9th edn., OUP, 2019), at 118.

13 Crawford, supra note 3 , at 37.

14 Shaw Amicus Brief, supra note 7, 17 (acknowledging that recognition and self-determination 'may possibly bear upon the application of the Montevideo criteria').

15 See the examples discussed in this Section. 
there is growing practice supporting a flexible interpretation and application of those criteria. There is nothing unusual about this: as international law evolves over time, so do the rules on statehood.

Accordingly, the authors believe that the Montevideo criteria should not be treated as the ultimate 'checklist' to determine whether a particular entity is a state, nor should they be applied strictly. Following a similar argumentation, Malcolm Shaw concluded that the Montevideo criteria 'are neither exhaustive nor immutable' ${ }^{17}$ Rather, there are circumstances warranting a more flexible application in which not all the conditions need to be fulfilled, or in which the application of further conditions may be necessary. ${ }^{18}$ Thus, the conclusion seems warranted that, while the classic Montevideo criteria 'still form the initial and basic normative requirements for assessing statehood, their complete fulfilment is no longer the exclusive yardstick' ${ }^{19}$ Effectiveness remains the main general criterion for statehood, ${ }^{20}$ but there are other considerations at stake. Independence, recognition and legitimacy may play a role in assessing whether an entity claiming statehood should be regarded as a state. In conclusion, statehood has to be assessed on a case-by-case basis, in light of all the relevant circumstances. This also applies to the situation of Palestine.

Because occupation presupposes that the occupying power has acquired effective control over the occupied territory, ${ }^{21}$ the question arises whether occupation has an impact on the interpretation and application of the Montevideo criterion of 'government' with respect to the occupied entity. Before turning to that question in the next section, this article will examine the criterion of government more closely. Article 1 of the 1933 Montevideo Convention provides that for an entity to achieve statehood it must have a 'government' which in practice has been required to be 'effective'. ${ }^{22}$ An 'effective government' is one that has 'some degree of maintenance of law and order and the establishment of basic institutions'. ${ }^{23}$ James Crawford in his seminal work on the creation of states has defined 'government' as the 'exercise of authority ... within the territory of the State'. ${ }^{24}$ He further elaborated

16 E.g., the Turkish Republic of Northern Cyprus, which was proclaimed in 1983 by the Turkish Cypriot community in Northern Cyprus, following Turkey's 1974 unlawful military intervention in Cyprus, is not recognized as a sovereign state (with the exception of Turkey). Rhodesia's declaration of independence was not recognized by the UNSC and the UNGA because it breached the right to self-determination. See J. Crawford, 'State', MPEPIL (2011); Shaw Amicus Brief, supra note 7, § 22 .

17 Shaw, supra note 12, at 158.

18 Crawford, supra note 12 , at 118.

19 Z. Nevo and T. Megiddo, 'Lessons from Kosovo: The Law of Statehood and Palestinian Unilateral Independence', 5 Journal of International Law and International Relations (2013) 89115 , at 95 .

20 Crawford, supra note 3, at 98.

21 Art. 42 of the 1907 Hague Regulations.

22 Art. 1 Montevideo Convention.

23 Crawford, supra note 3, at 59.

24 Ibid., at 55. 
that 'to be a State, an entity must possess a government ... to the exclusion of other entities not claiming through or under it'. ${ }^{25}$

However, the level of effectiveness required under Article 1 of the Montevideo Convention depends on the circumstances and should be seen as a relative criterion. ${ }^{26}$ There is no universal and immutable threshold of effectiveness that an entity has to meet for achieving statehood. This interpretation is confirmed by state practice. The Vatican City is an example of a state where 'the strength and influence of the government - the Holy See - have compensated for a tiny territory and the lack of a permanent population' ${ }^{27}$ But there have been various examples of entities achieving statehood despite not having an effective government - at least not if one interprets that notion strictly.

The Democratic Republic of the Congo (DRC) is an example of an entity that achieved statehood (following its declaration of independence in 1960) while not having an effective government. ${ }^{28}$ At that time, the DRC was still dealing with various secessionist movements, its central government was divided in two factions (each one of them claiming to be the lawful government), and the new state was also in need of international aid because its authorities were bankrupt. ${ }^{29}$ For example, the UN Security Council (UNSC) in Resolution 143 decided to provide assistance to the DRC government until the latter was able to 'meet fully [its] tasks' while calling upon Belgium to withdraw its troops from the DRC's territory. ${ }^{30}$

In 1992, both Bosnia-Herzegovina and Croatia were also recognized by the European Community as independent states despite having limited effective control over their respective territory. ${ }^{31}$ They were also admitted to the UN although non-governmental forces 'controlled substantial areas of the territories in question in civil war conditions'. ${ }^{32}$ Had the requirement of effective government been applied strictly, neither Bosnia-Herzegovina nor Croatia could have been regarded as states proper.

The recognition of Namibia and Guinea-Bissau further supports the interpretation that the notion of effective government has been applied flexibly. In fact, as will be discussed in more detail below - and similar to the situation in Palestine - both entities did not completely fulfil the Montevideo criteria at the time when they were recognized as states because their territory was under occupation, but they were nonetheless regarded as states. ${ }^{33}$ These examples further show that recognition may be particularly relevant when

25 Ibid., at 59.

26 Ibid., at 61.

27 Crawford, supra note 3, at 223.

28 Shaw, supra note 12, at 162 (referring to a 'virtual breakdown of government').

29 Crawford, supra note 3, at 56-57.

30 UNSC Res 143, 14 July 1960, § 2.

31 Evans, supra note 11, at 202.

32 Shaw, supra note 12, at 159-160. Other examples include Rwanda, and Burundi, see R. Higgins, Problems and Process: International Law and How We Use It (OUP, 1994), at 40.

33 See Sections 3.B. and 4. 
an entity fails to satisfy the 'effective government' criterion. ${ }^{34}$ The foregoing considerations relate to Palestine's situation insofar as it is deemed not to have an 'effective' government, if one interprets that notion strictly.

This flexible interpretation of the requirement of effectiveness is also consistent with the fact that international law does not require the central government to exercise effective control over the entirety of a state's territory for that entity to be considered a state. By the same token, an independent state whose central authorities lose control over part of the territory does not, for that reason, cease to be a state. ${ }^{35}$

\section{Occupation Prevents the Occupied State from Having an Effective Government but Does not Affect Statehood}

This contribution now turns to its central argument: the effect of the law of belligerent occupation on the determination of statehood. Article 42 of the 1907 Hague Regulations (HR) is the cornerstone of, and lays down the conditions for triggering the law of occupation. Pursuant to that provision, which is considered to reflect customary international law, ${ }^{36}$ occupation arises when a territory is 'actually placed under the authority of the hostile army'. Authority of the hostile army in Article $42 \mathrm{HR}$ refers to the ability of the foreign forces to exert authority - understood as governmental functions ${ }^{37}$ - in the concerned territory in lieu of the local government. ${ }^{38}$ In general, the occupying power must exert 'effective control' to create a state of occupation. The effective control test has three main conditions: ${ }^{39}$ (1) the occupying power has rendered the incumbent government incapable of exercising its authority in the area; (2) the occupying power can substitute its own authority for that of the legitimate power; (3) exercise of authority by the occupying power takes place without the consent of the local government. ${ }^{40}$

Whether the effective control required for establishing a regime of belligerent occupation must be actual or potential is unsettled. 'Actual' control is a corollary of the physical presence and concrete exercise of authority of the armed forces of a foreign state on the occupied territory. ${ }^{41}$ 'Potential' control is linked

34 See further Section 4.

35 Shaw, supra note 12, at 160; Crawford, supra note 3, at 34.

36 ICJ, Legal Consequences of the Construction of a Wall in the Occupied Palestinian Territory, ICJ Reports (2004) 136 (hereafter Wall Opinion), § 78.

37 T. Ferraro, 'Determining the Beginning and End of an Occupation under International Humanitarian Law', 94 International Review of the Red Cross (2012) 133-163, at 148.

38 E. Benvenisti, The International Law of Occupation (OUP, 2012), at 188.

39 For more details on this, see e.g. Ferraro, supra note 37.

$40 \mathrm{H}$. Cuyckens, 'Is Israel Still an Occupying Power in Gaza?', 63 Netherlands International Law Review (2016) 275-295, at 278-279. Ferraro, supra note 37, at 142, frames the three conditions in equivalent, although slightly different, terms: "unconsented-to presence of foreign forces, the foreign forces' ability to exercise authority over the territory concerned in lieu of the local sovereign, and the related inability of the latter to exert its authority over the territory.' 
to the capability of the enemy forces to exercise authority over the occupied territory. ${ }^{42}$ In Naletilić, a Trial Chamber of the International Criminal Tribunal for the former Yugoslavia (ICTY) adopted the view that potential control is sufficient for occupation and set out some guidelines to determine whether the authority of the occupying power has been actually established within the meaning of Article $42 \mathrm{HR}^{43}$ Amongst these, it included the presence of sufficient forces by the occupying power, 'or the capacity to send troops within a reasonable time to make the authority of the occupying power felt' ${ }^{44}$ Under this view, physical presence on the ground is not required to establish occupation, or to maintain it. Opinions are divided on this matter. The prevalent view amongst scholars, which echoes the case-law of international and domestic courts, ${ }^{45}$ is that boots on the ground are required to establish effective control, at least in the initial phase of the occupation. ${ }^{46}$ According to some, while physical presence is necessary to establish occupation, it is not necessary for maintaining it once it is established. ${ }^{47}$ In other words, effective control can also be maintained 'remotely'. ${ }^{48}$ In our view, the latter interpretation is preferred as it is more in line with the object and purpose of the IHL rules regulating occupation, i.e. to protect civilians when they are subject to the effects of occupation or armed conflict. If the occupying power has the ability to exercise effective control over the occupied territory at any time (e.g. by using helicopters, drones or quickly launched ground forces) there is no reason why the IHL framework of belligerent occupation should not apply. In this regard, the 'potential' effective control leaves no gap in the protection afforded to persons in the occupied area and prevents an occupying power from evading its responsibilities under IHL by failing to exercise governmental authority which it would have the ability to exercise. With this interpretation, effective control by the occupying power stays at the very heart of occupation, but is

41 ICRC Expert Meeting on 'Occupation and Other Forms of Administration of Foreign Territory', Report (2013) (hereafter ICRC Expert Meeting on Occupation), at 19-20; ICJ, Armed Activities on the Territory of the Congo (DRC v. Uganda), ICJ Reports (2005) 168, § 173

42 ICRC Expert Meeting on Occupation, supra note 41, at 19-20; Cuyckens, supra note 40, at 280.

43 Judgment, Naletilić and Martinović (IT-98-34-T), Trial Chamber, 31 March 2003, § 217.

44 Ibid.

45 ICJ, Armed Activities, supra note 41, 173 (referring to the presence of Ugandan forces on the territory of the DRC as a necessary element to establish that Uganda was an occupying power); ECtHR, Sargsyan v. Azerbaijan, Report of Judgments and Decisions 2015, § 94, and Chiragov v. Armenia, Report of Judgments and Decisions 2015, § 96. See also High Court of Justice, Israel, 9132/07, Jaber Al-Bassiouni Ahmed and Others v. Prime Minister and Minister of Defence, 30 January 2008, § 12 .

46 See the records of the discussion during the ICRC Expert Meeting on Occupation, supra note 41, at 17-19. See also Y. Shany, 'Faraway, So Close: The Legal Status of Gaza after Israel's Disengagement', 8 Yearbook of International Humanitarian Law (2005) 369-383, at 380; Ferraro, supra note 37 , at 142 et seq.

47 Cuyckens, supra note 40, at 281; Dinstein argued that troops do not need to be placed in the territory itself, but could be in its vicinity: Y. Dinstein, The International Law of Belligerent Occupation (CUP, 2009), § 100.

48 Under this view, the Gaza Strip would have the legal status of occupied territory despite Israel's disengagement. 
adapted to the modern possibilities of warfare where a state can be in control of a territory without necessarily having a physical presence there at all times.

It is important to stress that occupation does not affect a state's sovereignty or its territorial integrity. ${ }^{49}$ As Yoram Dinstein put it: '[t]he main pillar of the law of belligerent occupation is embedded in the maxim that the occupation does not affect sovereignty'; and 'the sovereignty of the displaced sovereign over the occupied territory is not terminated. It is not even suspended'. ${ }^{50}$ However, when it comes to the determination of statehood, the occupying power's exercise of authority over the occupied territory is in sharp contradiction with the requirement that the occupied entity must possess an effective government in order to be considered a state, pursuant to Article 1 of the Montevideo Convention. As Liron Libman argued: '[f]oreign occupation and independent government are mutually exclusive categories. ${ }^{51}$ This view is not surprising, given that the establishment of effective control by the occupying power implies that the occupying power has rendered the incumbent government incapable of exercising its authority in the area. The European Court of Human Rights (ECtHR) in Ilaşcu v. Moldova and Russia, ${ }^{52}$ Loizidou v. Turkey, ${ }^{53}$ and Cyprus v. Turkey ${ }^{54}$ recognized that in a regime of belligerent occupation, the occupying power effectively controls the territory concerned and as such, prevents the occupied state 'from exercising its authority in part of its territory' ${ }^{55}$ Moreover, the powers conferred to the occupant by the law of occupation are rather permissive and extensive, ${ }^{56}$ which in many ways contradicts the assumption that the occupied state is able to have an effective government for the duration of the occupation. Consequently, while commenting on Geneva Convention (GC) IV, Jean Pictet recognized that occupation interferes with the occupied power's ability to exercise its sovereign rights. ${ }^{57}$ To put it bluntly: occupation results in the inability of the occupied entity to exercise effective control over its own territory. ${ }^{58}$ As a consequence, an occupied state will usually not be in possession of an 'effective government' as required by

49 J.S. Pictet, O.M. Uhler and R. Griffin, The Geneva Conventions of 12 August 1949: Commentary, Vol. IV: Geneva Convention relative to the Protection of Civilian Persons in Time of War (ICRC, 1958) (hereafter Commentary to GC IV), at 275.

50 Dinstein, supra note $47, \S 113$.

51 L. Libman, 'The ICC's Prosecutor Decision to Investigate the "Situation in Palestine" and Palestinian Statehood', Lawfare, 15 January 2020, available online at www.lawfareblog.com/ iccs-prosecutor-decision-investigate-situation-palestine-and-palestinian-statehood. See also State of Israel Ministry of Foreign Affairs, 'The International Criminal Court's Lack of Jurisdiction over the So-Called "Situation in Palestine", 20 December 2019, § 24, available online at https:// mfa.gov.il/MFA/PressRoom/2019/Pages/ICCs-lack-of-jurisdiction-over-so-called-situation-inPalestine-20-Dec-2019.aspx.

52 Ilascu v. Moldova and Russia, 8 July 2004, Reports of Judgments and Decisions 2004-VII, at 312-313.

53 Loizidou v. Turkey (Preliminary Objections), 23 March 1995, Series A 310.

54 Cyprus v. Turkey, 10 May 2001, Reports of Judgments and Decisions 2001-IV, §§ 76-83.

55 Ilascu, supra note 52, at 312-313.

56 Commentary to GC IV, supra note 49, at 337. The occupant's powers are regulated in Arts 43 and $47 \mathrm{HR}$, as well as in Arts 64(2), 65 and 66 of GC IV.

57 Ibid., at 275 . 
Article 1 of the Montevideo Convention. Yet, the fact that a state is (temporarily) occupied and therefore lacks an effective government does not make it any less of a state. The decisive impact occupation has on a state concerns the exercise of its governmental and administrative functions, not its existence as a state or its sovereignty.

When applying those considerations to the situation of Palestine - and the question of its territorial jurisdiction before the ICC - it is important to note that the International Court of Justice (ICJ) in its Wall Opinion has clearly confirmed that Israel exercises control over the OPT. ${ }^{59}$ Therefore, the existing status of occupation inherently prevents the fulfilment of the conditions laid down in Article 1 of the 1933 Montevideo Convention, if applied strictly to Palestine's situation. ${ }^{60}$ Consequently, an occupier cannot complain that an occupied entity does not fulfil the criterion of effective government, as it is the occupier itself that sets the factual reason why the effectiveness of the government is hampered.

Instituting military rule over a territory may coexist with the continued exercise of some degree of authority by the local government. This will often not make the local authorities an effective government (although there is of course the possibility that at one point the local authorities will have gained sufficient independence), nor does it negate effective control by the occupying power. In this regard, another important question concerns the effect of prolonged occupation on the occupied state's ability to exercise governmental functions. Undoubtedly ' $[\mathrm{t}$ ] he passage of time ... cannot extend the authority of the military commander and allow him to take into account considerations beyond the proper administration of the area under belligerent occupation' ${ }^{61}$ The Commentary to Article 6(3) GC IV suggests that, in the 1949 delegates' view, 'if the occupation were to continue for a very long time after the general cessation of hostilities ... most of the governmental and administrative duties carried out at one time by the occupying power [would have] been handed over to the authorities of the occupied territory ${ }^{62}$ Thus, in theory the local authorities should assume more and more responsibilities regarding the exercise of governmental powers. But unfortunately, reality has shown us that a prolonged occupation does not necessarily imply that the occupied entity is more likely to acquire effective governmental authority as time goes by. On the contrary, the longer a regime of occupation is in place, the more governmental functions the occupying power will naturally assume, especially with regard to the exercise of legislative functions. When the occupation has a protracted character, as in the case of Palestine, 'many practical problems may arise that do not admit of mere temporary solutions based on the idea of preserving

58 Amicus Curiae Observations by the International Commission of Jurists (Pursuant to Rule 103 of the Rules), Situation in the State of Palestine (ICC-01/18), Pre-Trial Chamber I, 16 March 2020 (hereafter ICJ Amicus Brief), § 27.

59 ICJ, Wall Opinion, supra note 36, §78; see also $§ 139$.

60 Commentary to GC IV, supra note 49 , at 274-275.

61 Beit Sourik Village Council v. The Government of Israel, HCJ 2056/04, 30 June 2004, § 27.

62 Commentary to GC IV, supra note 49 , at 62 . 
the status quo ante: decisions may have to be taken about such matters as road construction, higher education, water use, electricity generation and integration into changing international markets'. ${ }^{63}$ Accordingly, Adam Roberts considers that ' $[\mathrm{t}$ ] he provision [enshrined in Article 6(3) GC IV] has never been formally implemented, was in effect rescinded by Protocol I and must be regarded as a failure'. ${ }^{64}$ This shows that local authorities seldom assume more responsibilities as the occupation gets more protracted; it is rather very often the case that the occupying power assumes more government authority.

In Palestine's case, the Oslo Accords provided for the creation of the Palestinian Interim Self-Governing Authority, and the partial transfer of authority to it over a five-year transitional period. ${ }^{65}$ The Palestinian National Authority (PNA) was established in 1994. However, the PNA's authority is largely limited to Areas A and B of the West Bank, to the exclusion of Area C, and it is subject to significant limitations. ${ }^{66}$ The Oslo Accords remain largely unimplemented, and in May 2020 PNA President Abbas declared that Palestinians are no longer bound by any arrangements with Israel, including the security ones. ${ }^{67}$ All the while, Israel continues to exercise effective control over the OPT, and its status remains that of an occupying power, as confirmed by the ICJ. ${ }^{68}$

\section{A. The Violation of the IHL Rules on Belligerent Occupation by the Occupying Power Needs to be Taken into Account When Determining the Occupied Territory's Statehood}

The occupied entity's inability to have an effective government is even more marked if the occupying power adopts legislative, executive or other measures that exceed the authority granted to it under the law of occupation, and therefore violates IHL. By so doing, arguably an occupant would de facto exercise sovereignty rights over the occupied territory. Such measures would significantly restrict both the ability of the reversionary sovereign to exercise any form of governmental functions over its territory, and the capacity of the occupied people to exercise its right to self-determination. It can be argued that Israel has adopted measures in breach of IHL, as discussed below, ${ }^{69}$ that have curtailed Palestinian authorities' ability to carry out the functions of government. In her request for a ruling on the scope of territorial jurisdiction,

63 A. Roberts, 'Prolonged Military Occupation: The Israeli-Occupied Territories since 1967', 84 American Journal of International Law (1990) 44-103, at 52.

64 Ibid., at 95.

65 Declaration of Principles on Interim Self-Government Arrangements, 11 October 1993 ('Oslo I'), Art. 1.

66 Arts IX(5)(a), X(4) Oslo II.

67 The State of Palestine's response to the Pre-Trial Chamber's Order requesting additional information, Situation in the State of Palestine (ICC-01/18-12), Pre-Trial Chamber, 4 June 2020, Annex A. The statement has been interpreted as encompassing the Oslo Accords.

68 ICJ, Wall Opinion, supra note $36, \S 78$.

69 See below the text accompanying notes 70 to 76 . 
the ICC Prosecutor explains how the construction of the separation barrier and its associated regime, and the expansion of the settlements, obstruct 'Palestine's viability as a State (and the exercise of the Palestinian people's right to self-determination) ${ }^{70}$

For the purposes of the present analysis it bears emphasizing - without repeating the full argument on the illegality of those measures - that they have a severe impact on Palestinian authorities' ability to exercise governmental functions in the OPT. Their effects include the fragmentation of Palestine's territory, ${ }^{71}$ restrictions to the freedom of movement of Palestinian people, ${ }^{72}$ the extraterritorial application of Israeli domestic law to a growing number of settlers living in Area $\mathrm{C}$, and thus on Palestine's territory, while Palestinians are subjected to military law. ${ }^{73}$ Similarly, other measures taken by Israel in violation of IHL negatively impact Palestine's ability to carry out governmental functions in the OTP. For example, following Israel's annexation of East Jerusalem in $1980^{74}$ - which constitutes a blatant violation of international law $^{75}$ - Palestinians authorities are prevented from exercising any form of rule over that part of their territory. Therefore, if Palestine does not meet a strict standard of effective government under the Montevideo Convention, this is partly due to Israel's protracted military occupation and to certain measures that exceed Israel's authority under the law of belligerent occupation and constitute violations of IHL. ${ }^{76}$

\section{B. Entities Lacking an Effective Government because of Occupation Have Been Recognized as States}

There are two important examples from recent state practice which show that entities can acquire statehood while under belligerent occupation. The first is the recognition of Guinea-Bissau as an independent state. On 24 September 1973, Guinea-Bissau declared its independence from Portugal, the occupying power. In its Resolution 3061 of 2 November 1973, the UN General Assembly (UNGA) welcomed the creation of the 'sovereign State of the Republic of Guinea-Bissau' while condemning the illegal occupation of Portugal's forces in the newly formed state. ${ }^{77}$ The resolution received the support of 93 States.

70 Prosecution Request, § 146; see also §§ 138, 157-177.

71 See e.g. UNGA Res. 73/98, 7 December 2018, Preamble $§ 7$.

72 ICJ, Wall Opinion, supra note 36, §§ 133-134.

73 L. Daniele, 'Enforcing Illegality: Israel's Military Justice in the West Bank', 44 Questions of International Law (2017) 21-40, at 29-32 (defining the application of Israeli law to the settlers 'jurisdictional annexation'); B’Tselem, 'The Military Courts', 11 November 2017, available online at www.btselem.org/military_courts.

74 Basic Law: Jerusalem, Capital of Israel, 34 Laws of the State of Israel 209 (1980), available online at www.knesset.gov.il/laws/special/eng/basic10_eng.htm.

75 See UNSC Res. 478, 20 August 1980; Report of the Special Rapporteur on the situation of human rights in the Palestinian territories occupied since 1967, UN Doc. A/72/556, 23 October 2017, \$§ 27-38.

76 See also ICJ Amicus Brief, supra note 58, § 49.

77 UNGA Res. 3061, 2 November 1973, para. 1. 
It is important to note that the liberation movement of Guinea-Bissau, the African Party for the Independence of Guinea and Cape Verde, at the time of the declaration of independence had substantial control over certain areas of its territory, while Portugal was only occupying cities and some military areas. ${ }^{78}$ In this regard, one might be able to compare this situation with the realities of the OPT, which also experiences different levels of occupation. ${ }^{79}$ The UNGA soon thereafter recognized Guinea-Bissau as an 'independent State' from Portugal. ${ }^{80}$ Following recognition by the UNGA, Guinea-Bissau acceded to several international organizations while Portugal still had not recognized its independence. ${ }^{81}$ Guinea-Bissau's declaration of independence was recognized by 70 states with Portugal recognizing its independence a year later. ${ }^{82}$

Similarly, after Palestine proclaimed its independence on 15 November 1988, the UNGA in Resolution 43/77 'affirm[ed] the need to enable the Palestinian people to exercise their sovereignty over their territory occupied since 1967, ${ }^{83}$ The state of Palestine was recognized by 104 states after declaring its independence ${ }^{84}$ and is currently recognized by 138 states. $^{85}$ In 2011 , Palestine was admitted as a member state of the UN Educational, Scientific and Cultural Organisation (UNESCO), ${ }^{86}$ which requires, in Article II(2) of its Constitution, statehood as a condition for membership. ${ }^{87}$ In 2012, while hoping that the UNSC would favour Palestine's admission to full membership, ${ }^{88}$ the UNGA granted Palestine the status of non-member observer state with Resolution 67/19. ${ }^{89}$ Amongst the 138 states which voted in favour, many delegations expressed that such Resolution was a landmark for a 'two-State solution'. 90 This paved the way for further recognition of the state of Palestine and its inclusion in other international organizations. In 2015, Palestine

78 P. Pierson-Mathy, La naissance de l'État par la guerre de libération nationale: le cas de la GuinéeBissau (UNESCO, 1980), at 23.

79 Israel withdrew ground forces from the Gaza Strips while it still maintains boots on the ground in the West Bank. See UNSC Press Release, 'Israel's Disengagement from Gaza, Northern West Bank "Watershed", Under-Secretary-General Tells Security Council”, SC/8479, 24 August 2005.

80 UNGA Res. 3181(XXVIII), 17 December 1973.

81 See Section 4 below.

82 UNGA Res. 3061, 2 November 1973; J. Salmon, 'La proclamation de l'Etat palestinien', 34 Annuaire français de droit international (1988) 37-62, at 61.

83 UNGA Res. 43/77, 15 December 1988, § 2.

84 Ibid.

85 Permanent Observer Mission of the State of Palestine to the United Nations, 'Diplomatic

Relations', available online at http://palestineun.org/about-palestine/diplomatic-relations;

UNGA, Report of the Committee on the Exercise of the Inalienable Rights of the Palestinian People, 4 August 2019, UN Doc. A/74/35, § 17.

86 UNESCO, Records of the General Conference (Vol. I, Resolutions, 36th session), at 79.

87 Constitution of UNESCO, Art. II.2.

88 UNGA Res. 67/19, 29 November 2012, § 3.

89 Ibid., $§ 2$.

90 UNGA Press Release, "General Assembly Votes Overwhelmingly to Accord Palestine "NonMember Observer State” Status in United Nations', GA/11317, 29 November 2012, available online at www.un.org/press/en/2012/ga11317.doc.htm. 
became a member of the Permanent Court of Arbitration, ${ }^{91}$ the World Customs Organisation, ${ }^{92}$ and most importantly, the ICC. ${ }^{93}$

The situation in Palestine is also analogous to the historic example of Namibia. Despite South Africa's occupation of Namibia, in 1978, the International Labour Organisation (ILO) found Namibia to be a state which could be admitted to the organization on the ground that 'the legitimate rights of the Namibian people [should not] be frustrated by the illegal actions of South Africa'. ${ }^{94}$ At the time Namibia did not have an effective government, nor was it independent, as it was still controlled by South Africa and administered by the UN Council for Namibia, an agency that the UNGA created in 1967.

Albeit limited, these precedents are nonetheless significant. They show that entities lacking an effective government due to foreign occupation have nevertheless been recognized as states. Therefore, the requirement of effective government is not a strict condition. Scholarly opinions confirm this interpretation. For example, Steven Kay and Joshua Kern argue that 'entities formed under belligerent occupation might, if able to establish independence vis-à-vis the occupant, become a State, subject to cessation of hostilities or with recognition by the previous sovereign'. ${ }^{95}$ However, in their view 'an entity claiming statehood but created during a period of foreign military occupation will be presumed not to be independent ${ }^{96}$ In contrast, John Quigley notes that an entity can achieve statehood even if it lacks independence due to foreign occupation, as was the case with Namibia. ${ }^{97}$ While this section makes clear that the 'effective government' criterion is not dispositive on the issue of statehood of an occupied entity, the next section will examine the particular ways an entity may overcome a failure to meet this criterion.

\section{Factors Mitigating Deficiencies in the 'Effective Government' Criterion for Occupied States}

In the authors' view, some deficiencies in the criterion of effective government due to occupation may be balanced against the principle of self-determination and international recognition. The article will first discuss the relevance of selfdetermination, and then turn to recognition.

91 PCA, 'New PCA Member State: Palestine', 15 March 2016, available online at https://pca-cpa. org/en/news/new-pca-member-state-palestine.

92 WCO, 'The WCO now has 180 Members', 19 May 2015, available online at www.wcoomd.org/ en/media/newsroom/2015/may/the-wco-now-has-180-members.aspx.

93 Rome Statute of the International Criminal Court, UNTS 2187, at 3.

94 ILO, 'Resolution on the Admission of Namibia', Selection Committee, 64th session (7-28 June 1978), at 50. See also Quigley, supra note 5, at 223.

95 Kay and Kern, supra note 3.

96 Ibid. In this regard, Crawford, supra note 3, at 438, argued in 2007 that Palestine could not be considered independent yet, but its people is entitled to self-determination.

97 Quigley, supra note 5, at 224-225. 
When it comes to determining the statehood of emerging states, 'the principle of effectiveness is not usually employed as the definitive explanation' ${ }^{98}$ In particular, scholars agree that the principle of self-determination can "mitigate the effects of a deficiency in effective control in particular circumstances', ${ }^{99}$ even if they disagree that this principle applies to Palestine. According to Shaw, '[s]elf-determination may arguably serve to mitigate the absence of effective governmental control where the colonial power is contesting the proclaimed independence of the accepted colonial self-determination unit', ${ }^{100}$ or 'where the new state is in the throes of a civil war'. ${ }^{101}$ However, in his view this principle does not apply to Palestine's situation, 'where the absence of effective control is neither imposed from without nor exists as a consequence of civil war'. ${ }^{102}$ This proposition fails to take into account that belligerent occupation is a form of 'alien domination' within the meaning of the resolution on the definition of aggression, and that it entitles the occupied people to selfdetermination. $^{103}$ Moreover, like colonial domination, occupation is also 'imposed from without'. Thus, keeping in mind the state practice in the colonial context, this contribution posits that self-determination can also mitigate the absence of effective governmental control in situations of belligerent occupation, especially in cases of protracted occupation and/or when the occupying power is violating the respective IHL framework. Palestine falls squarely within this framework.

The other factor to be taken into account when assessing whether an occupied entity that lacks an effective government meets the criteria for statehood is recognition. As stated above, recognition is not constitutive of statehood. ${ }^{104}$ However, as Shaw aptly put it, 'lack of effective central control might be balanced by significant international recognition, culminating in membership of the UN'. ${ }^{105}$ Shaw acknowledges that 'widespread and uncontroverted recognition by states (most definitively expressed by admission to membership of the UN) is likely to remedy, but not replace ... a certain deficiency in effective control exercised or not in fact by the central government'. ${ }^{106}$ Statehood and full UN membership are not synonymous, but the latter tends to create a presumption of full personality. ${ }^{107}$ Similarly, Jose Serralvo argues that the definition of 'government' should take into account not only an entity's internal effectiveness, but also its external effectiveness. Furthermore,

98 Evans, supra note 11, at 202.

99 Shaw Amicus Brief, supra note 7, § 47(iii).

100 Ibid., \$22

101 Ibid., $\$ 23$.

102 Ibid., \$ 30.

103 UNGA Res. 3314 (XXIX), 14 December 1974, Annex, Art. 7; see also Supreme Court of Canada, Reference re Secession of Quebec, [1998] 2 SCR 217, § 138; Roberts, supra note 63, at 80 ('the international community has tended not only to support self-determination in principle, but also - and increasingly — to view resistance against outside domination as justifiable').

104 See Section 1.

105 Shaw, supra note 12, at 160 .

106 Shaw Amicus Brief, supra note 7, § 20. 
in situations where an entity lacks the internal effectiveness to be considered a state, recognition can be considered constitutive. ${ }^{108}$

The authors - together with many other commentators - argue that Palestine's recognition as a 'non-member observer state' by the UNGA together with the previous and ensuing accession to various international organization should be considered a collective recognition by the international community of its statehood. ${ }^{109}$ This is consistent with the international community's recognition of Guinea-Bissau and Namibia, as mentioned above. The UNGA recognized the state of Guinea-Bissau with Resolution 3061 in 1973.110 Thereafter, Guinea-Bissau joined the African Union on 11 November 1973, and Food and Agriculture Organisation (FAO) on 26 November 1973, amongst others. ${ }^{111}$ Namibia was admitted as a member to several international organizations such as the ILO, FAO, the International Telecommunications Union (ITU) and the International Atomic Energy Agency (IAEA) after recommendations of the UN Council for Namibia promoted Namibia's membership to the UN specialized agencies. ${ }^{112}$ Namibia's membership was also recognized in several other international organizations such as the UN Conference on Trade and Development (UNCTAD), and the UN Industrial Development Organisation (UNIDO). ${ }^{113}$ Likewise, Palestine was accepted as a member state in various international organizations starting with the Organisation of Islamic Cooperation (OIC) in $1969,{ }^{114}$ UNESCO in $2011,{ }^{115}$ the UN which recognized it as a non-member observer state in 2012, ${ }^{116}$ the UN Office on Drug and Crime in $2014,{ }^{117}$ the ICC in $2015,{ }^{118}$ the Economic and Social Commission

107 M.L. Burgis-Kasthala, 'Over-stating Palestine’s UN Membership Bid? An Ethnographic Study on the Narratives of Statehood', 25 European Journal of International Law (2014) 677-701, at $680-681$.

108 J. Serralvo, 'Government Recognition and International Humanitarian Law Applicability in Post- Gaddafi Libya', 18 Yearbook of International Humanitarian Law (2015) 3-41, at 36-37.

109 E.g. H.G. Schermers and N.M. Blokker, International Institutional Law (6th edn., Brill, 2018), § 180; D. Akande, 'Palestine as a UN Observer State: Does This Make Palestine a State?', EJIL:Talk!, 3 December 2012, available online at www.ejiltalk.org/palestine-as-a-un-obser ver-state-does-this-make-palestine-a-state. Contra: Crawford, supra note 3, at 441.

110 UNGA Res. 3061, 2 November 1973.

111 FAO C73/REP Rapport de la Conférence de la FAO (10-29 Novembre 1973, 17ème sess), at 81 ( 66 out of 105 members voted in favour, with 57 favourable votes needed for admission).

112 UNGA Res. 31/149, 20 December 1976, § 3; UNGA Res 33/24, 29 November 1978.

113 UNGA, Report of the United Nations Council for Namibia, A/41/24, 41st session, Supp. No 24 (1986), at 16 .

114 OIC, 'Member States', available online at www.oic-oci.org/states/?lan=en.

115 UNESCO, Records of the General Conference, Resolutions, 36th Session, Vol. I (25 October-10 November 2011), at 78 .

116 UNGA Res. 67/19, 29 November 2012, § 2.

117 UNODC, 'Country Profile', available online at www.unodc.org/unodc/en/corruption/countryprofile/countryprofile.html\#?CountryProfileDetails=\%2Funodc $\% 2$ Fcorruption $\% 2$ Fcountry-pro file\%2Fprofiles\%2Fpse.html.

118 ASP ICC, 'States Parties to the Rome Statute', available online at https://asp.icc-cpi.int/en_ menus/asp/states\%20parties/asian\%20states/Pages/Palestine.aspx. 
for Western Asia (ESCWA), ${ }^{119}$ the International Criminal Police Organisation (INTERPOL) in 2017, ${ }^{120}$ and the Organisation for the Prohibition of Chemical Weapons, ${ }^{121}$ the UN Industrial Development Organisation ${ }^{122}$ as well as $\mathrm{UNCTAD}^{123}$ in 2018.

This shows that Palestine is recognized as a state by the majority of the international community. For instance, Article 4 of the Constitution of INTERPOL conditions its membership to 'any country'. ${ }^{124}$ While INTERPOL refused to grant membership to Palestine in $2010,{ }^{125}$ it approved Palestine's membership in $2017^{126}$ based on INTERPOL Resolution GA2017-86-RES-01. This Resolution on membership confirmed that the word 'country' in Article 4 of the Constitution shall be interpreted as 'state' and that each requesting country shall provide that it meets the criteria for statehood to be accepted as a member. ${ }^{127}$

Moreover, while acceding to the ICC on 2 January $2015,{ }^{128}$ the state of Palestine also successfully ratified 17 treaties, including the UN Convention on the Law of the Sea, ${ }^{129}$ the Convention on Cluster Munitions, ${ }^{130}$ the International Covenant on Civil and Political Rights, ${ }^{131}$ the Convention against Torture and other Cruel, Inhuman or Degrading Treatment or Punishment ${ }^{132}$ and the International Convention on the Elimination of All Forms of Racial Discrimination. ${ }^{133}$ These treaties are open for ratification, acceptance, approval or accession by 'states'. The fact that the depositary accepted Palestine's

119 ESCWA, 'Member Countries in Alphabetical Order as Designated by the UN', available online at www.unescwa.org/sites/www.unescwa.org/files/uploads/escwamss.pdf.

120 INTERPOL, 'The State of Palestine and the Solomon Islands become INTERPOL member countries', 27 September 2017, available online at www.interpol.int/Who-we-are/Membercountries/Asia-South-Pacific/PALESTINE.

121 OPCW, 'Member States', available online at www.opcw.org/about-us/member-states/palestine.

122 UNIDO, 'Member States List', available online at www.unido.org/member_states.

123 UNCTAD, 'Membership of UNCTAD and of the Trade and Development Board', available online at https://unctad.org/en/Pages/About\%20UNCTAD/UNCTADs-Membership.aspx.

124 INTERPOL Constitution, Art. 4.

125 INTERPOL, 'INTERPOL Membership - Historical Perspective Document' Appendix 1 of the GA2017-86-REP-01, at 12.

126 INTERPOL, supra note 120.

127 INTERPOL, Res. No. 1 GA-2017-86-RES-01, Annex 1, 3.

128 UN Depositary Notification, Rome Statute of the International Criminal Court, 17 July 1998, State of Palestine: Accession on 2 January 2015, C.N.13.2015.TREATIES-XVIII.10 (6 January 2015).

129 UN Depositary Notification, UN Convention on the Law of the Sea, 10 December 1982, State of Palestine: Accession on 2 January 2015, C.N.10.2015.TREATIES-XXI.6 (6 January 2015).

130 UN Depositary Notification, Convention on Cluster Munitions, 30 May 2008, State of Palestine: Accession on 2 January 2015, C.N.14.2015.TREATIES-XXVI.6 (6 January 2015).

131 UN Depositary Notification, International Covenant on Civil and Political Rights, 16 December 1966, State of Palestine: Accession on 2 April 2014, C.N.181.2014.TREATIES-IV.4 (9 April 2014).

132 UN Depositary Notification, Convention against Torture and other Cruel, Inhuman or Degrading Treatment or Punishment, 10 December 1984, State of Palestine: Accession on 2 April 2014, C.N.184.2014.TREATIES-IV.9 (9 April 2014).

133 UN Depositary Notification, International Convention on the Elimination of All Forms of Racial Discrimination, 7 March 1966, State of Palestine: Accession on 2 April 2014, C.N.179.2014.TREATIES-IV.2 (9 April 2014). 
accession suggests that they considered Palestine to possess sufficient attributes of statehood to be able to accede to those treaties. While an entity's accession to treaties per se does not make it a state, ${ }^{134}$ the other states parties' acquiescence to the depositary's acceptance can be taken to indicate that they regarded the accession as effective. ${ }^{135}$ As of today, the state of Palestine has successfully acceded to 70 multilateral agreements, ${ }^{136}$ including 14 protocols, ${ }^{137}$ with the UN Secretary-General acting in his capacity as depositary.

\section{The Rome Statute Grants the ICC Jurisdiction Over Situations of Belligerent Occupation}

The Rome Statute does not require that the central government of a state party has effective control over the entirety of its territory for the Court to exercise jurisdiction over that state's territory pursuant to Article 12(2)(a) of the ICC Statute. Notably, a Pre-Trial Chamber authorized the Prosecution to investigate alleged crimes committed on Georgia's territory occupied by Russian forces during the armed conflict in 2008, even though Georgia did not exercise effective control over South Ossetia at the relevant time. ${ }^{138}$ Similarly, in 2002, Cyprus became a party to the Rome Statute, ${ }^{139}$ although it does not have effective control over the northern part of the island, which Turkey has occupied since 1974. As William Schabas pointed out, '[i]t has never been suggested that Cyprus could not become a State Party, or that its ratification of the Statute did not give the Court jurisdiction over the island as a whole, in accordance with Article 12(2)(a)' ${ }^{140}$

Moreover, the Statute explicitly contemplates belligerent occupation as a factual situation in which the Court can exercise its jurisdiction. This is apparent from two distinct provisions in the Rome Statute. First, Article $8(2)$ (b)(viii) grants the Court jurisdiction over the war crime of the transfer of population to or from an occupied territory. ${ }^{141}$ Second, Article 8bis(2)(a) of the ICC Statute qualifies as an act of aggression "[t]he invasion or attack by the armed forces of a State of the territory of another State, or any military

134 W. Schabas, Opinion in Accordance with Article 103 of the Rules of Procedure and Evidence, Situation in the State of Palestine (ICC-01/18), Pre-Trial Chamber I, 16 March 2020 (hereafter Schabas Amicus Brief), § 9.

135 Heinsch and Pinzauti Amicus Brief, supra note 1, §§ 19-20.

136 UN Treaty Collection, 'Depositary Notification by the Secretary-General', available online at https://treaties.un.org/Pages/CNs.aspx?cnTab=tab2\&clang=_en.

137 Ibid.

138 Decision on the Prosecutor's request for authorization of an investigation, Situation in Georgia (ICC-01/15), Pre-Trial Chamber, 27 January 2016, §§ 6, 64.

139 Cyprus signed the Rome Statute on 15 October 1998 and ratified it on 7 March 2002; available online at https://asp.icc-cpi.int/en_menus/asp/states\%20parties/asian\%20states/ Pages/cyprus.aspx.

140 Schabas Amicus Brief, supra note 134, § 19.

141 Emphasis added. 
occupation, however temporary, resulting from such invasion or attack, or any annexation by the use of force of the territory of another State or part thereof'. ${ }^{142}$ The fact that the Statute speaks of occupation when defining the crimes over which the Court has jurisdiction shows that occupation does not affect a state's sovereignty over its territory, or the Court's jurisdiction over Rome Statute crimes. ${ }^{143}$ Any interpretation to the contrary would frustrate the object and purpose of codifying in the Rome Statute crimes committed in occupied territories. Simply put: it would be contrary to all reason to have included the war crime of transfer of population to or from an occupied territory if the respective member state would lose their statehood (and therefore its ICC membership, or the ability to trigger the ICC's jurisdiction) in case it became occupied.

Within the framework of the Rome Statute, occupation might become relevant when assessing the question of admissibility. In this context, the ICC would have to take into account the limits on the exercise of jurisdiction by an occupied sovereign. ${ }^{144}$ For example, without full control over the exercise of its territorial jurisdiction, Palestine might find itself unable to fulfil its duty to exercise criminal jurisdiction over those responsible for international crimes.

\section{Conclusion}

This contribution has shown that a status of belligerent occupation inherently precludes an occupied entity - in the current situation, Palestine — from having an effective government as required by the 1933 Montevideo Convention. The authors argue that examples of entities being recognized as states while under occupation, such as Guinea-Bissau and Namibia, coupled with the assessment made by eminent legal scholars on statehood, nonetheless confirm that the criterion of effective government is relative and needs to be applied flexibly.

In assessing whether an entity under belligerent occupation meets the criteria for statehood, lack of effective governmental authority must also be balanced against the principle of self-determination, especially in situations where the occupying power exceeds its authority under the law of belligerent occupation, and therefore violates IHL. Moreover, widespread international recognition, especially as expressed by UN membership, also mitigates deficiencies in effective government.

Applying these considerations to the situation of Palestine, the authors argue that the lack of effective government does not negate Palestine's statehood. Additionally, the wide recognition of Palestine at the $\mathrm{UN},^{145}$ in various

142 Emphasis added.

143 The State of Palestine's observations in relation to the request for a ruling on the Court's territorial jurisdiction in Palestine, Situation in the State of Palestine (ICC-01/18), Pre-Trial Chamber I, 16 March 2020, $\$ 49$.

144 Y. Shany, 'In Defence of Functional Interpretation of Article 12(3) of the Rome Statute', 8 Journal of International Criminal Justice (2010) 329-343, 339.

145 UNGA Res. 67/19, 29 November 2012, § 2. 
international organizations - which require statehood as a condition for membership $^{146}$ — and its ratification of 70 multilateral conventions further confirm that Palestine is a state under the rules of public international law and therefore is in a position to validly trigger the jurisdiction of the ICC. 